\title{
PENGANTAR KE FILSAFAT HIKMAH ('IRFÂN) ALLAMAH SAYYID MUHAMMAD HUSAIN THABTHABÂI
}

\author{
Oleh: Salahuddin Harahap
}

\begin{abstract}
Allamah Muhammad Husain al-Thabthabani succeeded in initiating the revival of philosophical thought in Iran and Qum after almost dimming after the death of Mulla Sadra. Although there are not many things that are truly new from his thoughts on Mulla Sadra Philosophy, it can be said that in his hands a number of Mulla Shadra's ideas which are considered complicated can be described quite well so that they are easy to understand. His thoughts on philosophy were at least contained in two of his very famous works, namely Bidâyatu al-Hikmah and Nihâyatu alHikmah which at the same time strengthened his position as the leading Philosophy after Mulla Sadra. That is why it is deemed necessary to discuss the thoughts of Allamah Muhammad Husayn al-Thabthabi's Philosophy.
\end{abstract}

Keywords: 'irfân, Allamah Sayyid Muhammad Husain Thabthabâi.

\section{A. PENDAHULUAN}

Pembahasan tentang hakikat keberadaan (wujûd) menjadi hal fundamental dalam tradisi pengkajian filsafat termasuk Filsafat Islam, sebab hal ini akan menjadi fondasi atas kontruksi bangunan pemikiran filsafat dalam berbagai dimensinya. ${ }^{1}$ Pemahaman terhadap wujud akan memberikan dampak strategis pada rumusan berbagai konsep lain seperti ontologi, teologi, epistemologi, hingga eskatologi. Karena itulah, maka topik ini tidak pernah dilewatkan oleh para filsuf dalam karya-karyanya sejak masa klasik, pertengahan hingga ke masa kontemporer saat ini. Perdebatan tentang hakikat wujud memang memiliki kerumitan tersendiri

${ }^{1}$ Zailan Moris, Revelation, Intellectual Intuition and Reason in the Philosophy of Mulla Shadra: An Analysis of The al-Hikmah al-Arshiyyah, (London \& New York: Roudledge 2003), hal. 88 
bagi filsuf, tidak hanya di kalangan filsuf muslim tetapi juga dalam tradisi filsuf Barat dan Eropa. ${ }^{2}$

Dalam tradisi Filsafat Islam, telah ditemukan sejumlah pendekatan dalam memahami hakikat wujud yang secara garis besar dapat dilihat sebagai berikut: Pertama, Mazdhab Masyaîyyah (Paripatetik) semisal AlFarabi dan Abu Ali Sina yang berpandangan bahwa terdapat dua jenis wujud yakni: Pertama, Wujud Tuhan yang merupakan wujud sejati (Wâjib al-Wujûd) yang wujudnya teraktualisasi secara mandiri, dan Kedua, Wujud Alam Semesta merupakan wujud potensial yang mungkin (Mumkin alWujûd). Alam tidak benar-benar memiliki wujud secara aktual dalam realitas samapi ia mendapatkan pelimpahan wujud dari Tuhan sebagai (Wâjb al-Wujûd).

Kedua, Mazdhab Isyrâqîyyah (Illuminasi) yang mengedepankan teori pencahayaan menempatkan Tuhan sebagai Cahaya Sejati sumber atas segala cahaya (Nûrun âlâ Nûrin) dan memposisikan alam sebagai limpahan cahaya--- Sukhrawardi menyebut Tuhan sebagai al-Ghaný dan alam sebagai al-Faqîr seterusnya dalam kontek mewujud al-Faqîr akan sangat bergantung dan membutuhkan al-Ghaný yang diaktualisasikan dengan pelimpahan cahaya sehingga al-Faqîr tidak benar-benar memiliki wujud hingga ia mendapat limpahan dari Cahaya Sejati yakni Tuhan. Ketiga, Mazdhab Wujûdîyyah yang terkesan memadukan pendapat dua Mazdhab sebelumnya, Mulla Shadra berpendirian bahwa wujud merupakan hakikat sempurna dan tidak berbilang melainkan tunggal (Unity of Being --- Wahdat al-Wujûd). Karenanya tidak ada perbedaan antara wujud Tuhan dengan Alam Semesta dari aspek hakikat Eksistensibaik TUhan maupun alam memiliki kemurnian eksistensi yang sama, tetapi terdapat perbedaan pada tingkatan kualitasnya, dimana Wujud Tuhan merupakan wujud tertinggi, adapaun alam tersusun di bawahnya (Tasýkîk al-Wujûd) ${ }^{3}$--- semakain tinggi kebutuhan suatu wujud akan wujud

2 UNESCO: Arab Muslim Civilization in the Mirror of the Universal: Philosophical Perspectives, (UNESCO:2010), hal. 81-82. Lihat juga, Jack Reynolds, Understanding Existentialism, (London \&Newyor: Roudlege, 2006), hal. 2-3.

${ }^{3}$ Prinsip kesatuan wujud menyiratkan pengertian bahwa di dalam wujud yang mempunyai kesatuan tersebut pada dasarnya ada hirarki dan tingkatan-tingkatan yang kemudian membentuk wujud secara keseluruhan. Hirarki atau gradasi ini menurut Shadra mulai dari tingkatan atau hirarki yang paling rendah sampai yang paling tinggi. Dan masing-masing tingkatan yang lebih tinggi mencakup tingkatan yang lebih rendah darinya demikian seterusnya sehingga sampai kepada prinsip kesatuan secara mutlak 
tertinggi yakni Tuhan, maka semakin rendah pula tingkatan eksistensi tersebut. ${ }^{4}$

Meskipun perbedaan pandangan tentang hakikat wujud antara ketiga Mazdhab Filsafat tersebut tampaknya sangat sederhana, namun hal ini telah dapat menjadi fondasi yang cukup kuat untuk melahirkan berbagai sintesa-sintesa yang hampir dapat disebut sebagai sesuatu yang baru pada Filsafat Mullah Shadra atas berbagai permasalahan dari mulai ranah eskatologis, spiritual, teologis, hingga pada konsep ilmu pengetahuan. Menyadari hal tersebut maka lahirlah gerakan filsafat baru di Persia tepatnya di Iran yang berorientasi meneruskan pemikiranpemikiran Mulla Shadra agar dapat berinteraksi dan menyahuti berbagai permasalahan di era modern dan aktual. Gerakan filsafat tersebut dikenal dengan Filsafat Mazdhab Qum atau Mazdhab al-Hikmah al-Mutaâliyyâh yang salah satu tokohnya bernama Allamah Muhammad Husain alThabthabâi.

Allamah Muhammad Husain al-Thabthabâi berhasil menggagas hidupnya kembali pemikiran filsafat di Iran dan Qum setelah hampir redup sepeninggal Mulla Shadra. Meskipun tidak terdapat banyak hal yang benar-benar baru dari pemikirannya terhadap Filsafat Mulla Shadra, namun dapat dikatakan bahwa di tangannnya sejumlah pemikiran Mulla Shadra yang dianggap rumit dapat diuraikan dengan cukup baik sehingga mudah untuk dipahami. Pikirannya tentang filsafat setidaknya tertuang dalam dua karyanya yang sangat terkenal yakni Bidâyatu al-Hikmah dan Nihâyatu al-Hikmah yang sekaligus mengokohkan kedudukannya sebagai Filsuf terkemuka pasca Mulla Shadra. Karena itulah maka dipandang perlu untuk membahas pemikiran Filsafat Allamah Muhammad Husain alThabthabâi.

\section{B. BIOGRAFI INTELEKTUAL SINGKAT}

Meskipun belakangan Thabthbâi dikenal sebagai ulama dan filsuf multi tanlenta yang menguasai banyak bidang ilmu, namun dalam tulisan ini akan dibatasi pada sejarah intelektual yang menlatarbelakangi hingga ia menjadi filsuf yang sangata berpengaruh terutama di Persia. Thabathaba'i yang memiliki nama lengkap Muhammad Husain Bin alSayyîd Muhammad Bin al-Sayyîd Bin Mirza Ali Asghar Syaikh al-Islâm al-

${ }^{4}$ Fazlu Rahman, The Philosophy of Mulla Sadra Shirazi, (Albany: State University of New York Press, 1975), hal. 27-29. Lihat juga, Mulyadi Kartanegara, Integrasi IImu: Sebuah Rekonstruksi Holistik, (Arasy Mizan, 2005), hal. 33-35. 
Thabathaba'i al-Tabrîzi al-Qhâdhi dilahirkan di Kota Tibriz pada Tahun $1321 \mathrm{H} / 1903 \mathrm{M}$ dalam sebuah keluarga yang sarat dengan perjuangan, karya, tradisi intelektual dan masih memiliki garis keturunan yang sampai kepada Nabi Muhammad Saw. ${ }^{5}$ Thabathaba'i menempuh pendidikan dasar dan menengah di kota kelahirannya. Setelah itu ia melanjutkan pendidikannya di Universitas Najaf, sebuah Universitas Syi'ah terbesar di Iraq. Di Universitas inilah ia banyak belajar tentang fiqh, ushul fiqh, sehingga ia banyak menguasai tentang prinsip-prinsip yurisprudensi dan menguasai metode berargumentasi dengan baik yang seterusnya menjadikannya seorang mujtahid yang cukup berpengaruh dalam bidang sosial dan politik. ${ }^{6}$

Belajar filsafat selama enam tahun dengan Maha Guru Tersohor bernama Sayyid Husâin Badkubâi diperkuat oleh Sayyid Abul Hasan Jelwah dan Agha Ali Mudarris Zununi dengan membedah teks-teks beririsi matan filsafat seperti Kitab al-Syifâ karya Abu Ali Sina, Tahzíb al-Akhlak karya Ibn Miskawaih, al-Asfar al-Arba 'ah karya Mulla Shadra, Tahmîd alQawâid karya Ibn Turkah serta kitab Manzûmah karya Mulla Hadi Sabziwari. Namun untuk mengokohkan pemahaman Thabthabâi dalam bidang Filsafat Sayyid Badkubâi mewajibkannya untuk belajar Ilmu Matematika, Logoka Analitis serta Ilmu Ukur Bidang dan Ruang yang diselenggarakannya dibawah bimbingan Filsuf dan Saintis yang diakui saat itu bernama Sayyid Abu al-Qâsim Kwansari.7 Seperti diketahaui bahwa tradisi filsafat Persia sangat dipengaruhi oleh pemikiran Mulla Shadra yang menggabungkan Paipatetik dengan Isyraqîyyah dan Wujûdîyyah maka selian menekuni teks-teks filsafat dan sains, Thabthabâi juga mendalami ilmu 'Irfan atau ma'rifat lewat jalan spiritual dengan mendalami kitab Fushûs al-Hikâm karya Ibnu Arabi. ${ }^{8}$

Penguasaannya atas Fushûs al-Hikâm tidak hanya memperkuat kontruksi intektualnya tetapi lebih jauh telah menjadikannya sesekali lebih

5 Lihat, Achmad Muchaddam Fahham, Tuhan dalam Filsafat Allamah Thabthaba 'i: Relevansi Pandangan Moral dengan Eksistensi Tuhan dalam Pandangan Realisme Instingtif, (Yogyakarta: Rausyanfikri Institute, 2012), hal. 11

6 Seyyed Hossein Nasr, "Muhammad Husain Thabthaba 'i" (1903-1981) dalam Jhon L. Esposito (ed), Oxford Encyclopedia of Modern Islam World, (New York: Oxford University Press, 1995, Vol 4), hal. 161.

7 Allamah Muhammad Husain Thabthabâi, sebuah auto biografi yang ditulisnya diterjemahkan menjadi "Hidupku" dalam, Inilah Islam: Upaya Mehamai seluruh Konsep Islam secara Mudah, (Bandung: Pustaka Hidayah,1996), hal. 16.

8 Lihat kembali, Achmad Muchaddam Fahham, Tuhan dalam Filsafat Allamah Thabthaba 'i... hal.13 
tampak sebagai seorang 'Arif atau Sufi daripada seorang Fulsuf jika dilihat dari kebiasaannya beribadah seperti puasa, shalat, baca al-Qurân dan lebih nayak melakukan penyendirian 'uzlah. Bahkan dalam kondisi tertentu hampir saja Thabthabâi diyakini telah mencapai Zuhud Tajrid dalam pengamalan 'Irfan. ${ }^{9}$ Tradisi inilah kemudian yang mendorongnya menulis salah satu kayanya yang tersohor al-Mizân fi Tafsîr al-Qurân.

Ditinjau dari aspek sosio politik di Iran Thabthabâi hidup pada tiga era yakni masa akhir Dinasti Qazan, masa Transisi Kekuasaan Muhammad Ali Syah dan Iran dibawah pengaruh colonial yang dipimpin oleh Reza Syah 1925. Pemikiran filsuf termasuk perkembangan dan coraknya tidak akan pernah lepas dari kondisi sosio kultural yang terjadi disekelilingnya, sebab kematangan intelektual dan spiritual secara otomatis akan mendorongnya untuk menjadi peka terhadap permasalahan yang sedang dihadapi umat terutama di negerinya. ${ }^{10}$ Sistem pendidikan di Iran saat itu sudah dipengaruhi oleh Eropa dan Barat sehingga terkesan telah mulai meninggalakan sipiritual menuju sekuler. Hal ini terbukti dengan semakin tingginya intensitas pengiriman pelajar dan mahasiswa ke Eropa dan Barat dan pendirian berbagai lembaga pendidikan modern sekuler di Iran. ${ }^{11}$

Menyadari kondisi tersebut, maka Thabthabâi melakukan pengembangan pemikirannya dengan mengintegrasikan rasionalitas dan spiritualitas, meneruskan tradisi Mulla Shadra yang berupaya mengintegrasikan tradisi pemikiran filsafat Islam mulai dari Paripatetik, Illuminasi hingga Wujudiyah yang seterusnya dikenal dengan ' Irfan'12 yang menjadi ciri pemikiran filsuf Iran atau Filsafat Mazdhab Qum. Metode 'Irfan tidak hanya diberlakukan dalam kajian filsafat dan teology, tetapi lebih jauh telah diaktualisasikan ke dalam kajian-kajian lain seperti Tafsir, Ushul al-Fiqh, hingga sosial dan Politik. Bahkan dapat dikatakan bahwa

9 Seyyid Hossein Nasr, Preface to the Book of Shiite in Islam by Allameh Tabatabaei, (Qum Iran, 2006) hal. 10.

${ }^{10}$ Babette.E. Babich (ed) Hermeneutic Philosophy of Science, Van Gogh's Eyes, and God: Essays in Honor of Patrick A. Heelan, S.J. (Kluwer Academic Publisher 2002), Logicism in philoshophy of sciences not only denies the living reality of scientific thinking but in the neglect of the role of the community it also denies the rality of our criteria for accepting and rejecting pultative additions to the stock of authentic sceientific knowledge. Hal. 221

11 Lihat, Abdul Shakoor Ahsan, "Renaissance in Iran: General" dalam MM. Sharief, (ed) A History of Muslim Philoshophy, Vol II (Pakistan: Royal Book Company, 1983), hal. 1525.

12 Mahdī Hā'irī Yazdī, The Principles of Epistemology in Islamic Philosophy: Knowledge by Presence, (New York: State University of New York Press, 1992), Hal. 2223. 
system pemerintahan Republik Islam Iran yang didasarkan kepada Wilâyat al-Fâqih merupakan wujud dari integrasi metode `Irfan dengan pemikiran politik. ${ }^{13}$ Atas dasar ini maka, untuk memahami pemikiran Thabthabâi mesti dilakukan lewat jalur `Irfan tersebut.

\section{PRINSIP DASAR FILSAFAT THABTHABÂI}

Filsafat Thabthabâi sesungguhnya merupakan lanjutan dari filsafat Mulla Shadra yang secara konsisten memelihara tradisi Filsafat Islam sejak al-Farabi hingga Ibnu 'Arabi sejak Masya'iyah hingga Wujûdîyyah. Namun dalam beberapa hal justru terlihat bahwa filsafat Thabthabâi merupakan penyederhanaan atau syarah atas pemikiran Mulla Shadra. Hal ini terlihat dari intisari pembahasan dua karyanya yang monumental dalam filsafat yakni: (1) Bidâyat al-Hikmah dan (2) Nihâyat al-Hikmah. ${ }^{14}$ Kedua buku ini menggambarkan filsafat Thabthabâi sekaligus mengukuhkannya sebagai salah seorang penerus terbaik dari filsafat Mula Shadra. untuk menguatkan pemikiran ini, berikut akan diuraikan beberapa pemikiran pokok yang dituangkan Thabthabâi dalam kedua kitab tersebut. Menurut Thabthabâi bahwa inti dari Filsafat itu sendiri adalah belajar tentang Maujûd, karenanya sebagian besar dari pembahasan dalam kitab Nihâyat al-Hikmah beris tentang permasalahan wujud. ${ }^{15}$ Lebih jauh dengan merujuk kepada Kata Pengantar yang ditulis Thabthabâi pada kitab Nihâyat al-Hikmah dapat dipahami bahwa bagi Thabthabâi kajian filsafat itu adalah kajian tentang al-Falsafah al-Ûla atau yang dikenal dengan Mâ ba 'da ath-Thâbiah yang itu berarti objek kajiannya adalah seputar wujud dan metafisika. ${ }^{16}$ Kitab Nihâyat al-Hikmah menjadi rujukan yang dipandang penting dalam pengajaran Filsafat pada Haujah di Qum dan Najaf bahkan hingga saat ini. Bahkan Tâqi Mishbah Yadzî yang merupakan filsuf berkat diantara murid Thabthabâi telah membuat sebuah anotasi

13 Lihat, Hamid Mavani, Religious Authority and Political Thought in Twelver Shi'sm: From Ali to Post Khomeini, (New York: Roudledge, 2013), Hal. 178-179.

14 Ktab Nihâyat al-Hikmat yang sebanrnya merupakan tulisan penting Thabthabâi tetapi tidak terlalu popular di kalangan filsuf termasuk di Iran, bahkan sebagian besar orang mengetahui tentang karya ini hanya karena pada setiap tulisan yang berhubungan dengan Allamah Thabthabâi pasti menginformasikan bahwa beliau menulis buku ini. Berbeda dengan bukunya yang berjudul Ushûl -e Falsafe wa Raves -e Realism yang ditulis Thabthabâi untuk meruntuhkan materialism dialektikal yang saat itu sedang digandrungi oleh banyak pemikir muda di Iran, lihat. Murthada Muthahari, Tematema Penting Filsafat Islam, (Bandung: Mizan, 1993), hal. 73.

15 Murthada Muthahari, Tema-tema... hal. 48, lihat juga, Achmad Muchaddam Fahham, Tuhan dalam Filsafat... Hal. 24.

16 Murthada Muthahari, Tema-tema... hal. 73-74. 
terhadap kitab tersebut yang diberi judul Ta ’liqah `alâ Nihâyat al-Hikmah yang titerbitkan pertama kali pada tahun 1986 setelah 5 tahun wafatnya Thabthabâi Tahun $1981 .{ }^{17}$

Seperti telah dijelaskan sebelumnya, bahwa Filsafat Thabthabâi merupakan integrasi dari pemikiran rasional dengan intuitif yang selanjutnya dikenal dengan Hikmah atai 'Irfan. Adapun prinsip-prinsip utama filsafat 'Irfan tersebut, adalah pendirian bahwa kebenaran 'Irfan diperoleh secara hudhûri (knowledge by presence), sehingga pengukuhan filsafat ini dapat dilakukan lewat optimalisasi perenungan spiritual secara kritis atau dapat disebut introspektif. Untuk memudahkan pemahaman atas capaian tersebut berikut disampaikan diktrin-doktrin paradigmatik dasar pendirian Filsafat Hikmah atau 'Irfan.

Pertama, 'Urafâ seperti halnya Thabthabâ berpendirian bahwa wujûd atau ada merupakan konsep sederhana yang secara langsung bisa dimengerti tanpa perantara konsep lain (badâhah mafhûm al-wujûd). ${ }^{18}$ Pendirian ini sebenarnya mirip dengan konsep Wajib al-Wujûd Ibnu Sina namun berbeda saat menjelaskan wujud alam semesta. Penganut 'Irfan sepakat dengan Ibnu Sina dalam menjelaskan keberadaan Tuhan sebagai wujud sempurna tanpa sebab tanpa konsep, namun berbeda saat menjelaskan eksistensi alam semesta. Ibnu Sina berpendirian bahwa alam semesta hanya merupakan konsepsi wujud bukan wujud hakiki, dan konsep ini baru akan teraktus manakala ia mendapat dukungan dari wujud hakikia Tuhan. Sehingga alama semesta menurut Ibnu Sina hanyalah Mumkin al-Wujûd sampai ia diboboti oleh Wajib al-Wujûd.

Kedua, doktrin kedua dari pemikiran Thabthbâ tentang wujud, adalah adanya kesatuan konsep wujud yang berlaku secara umum atas segala sesuatu dengan pengertian tunggal (mafhûm al-wujûd musytarakun ma'nawi). ${ }^{19}$ Dalam hal ini Thabthabâi seperti juga Mulla Shadra berkeyakinan bawa dari eksistensi atau keberadaan bersifat murni dan tunggal, tidak ada eksitensi yang semu atau mumkin, dengan kata lain eksistensi Tuhan dengan alam semsat dalam berbagai jenisnya adalah satu. Dalam pendirian ini tampaka adanya korelasi yang kuat antara pemikiran Thabthbâi dengan Ibnu Arabi dalam Wahdat al-Wujud, berbeda ketika menjelaskan realitas yang menunjukkan adanya keragaman wujud.

17 Achmad Muchaddam Fahham, Tuhan dalam Filsafat... Hal. 26.

18 Allamah Muhammad Husain Thabathabâi, Bidâyat Al-Hikmah, (Qum: Muassasah An-Nasyr Al-Islami, $1422 \mathrm{H})$, Hal. 11.

19 Thabathabâi, Nihâyat Al-Hikmah, (Qum: Muassasah An-Nasyr Al-Islami, 1422 H), hal. 12. 
Jika Ibnu Arabi mendeklarasikan adanya satu wujud hakiki dan menegasikan wujud lain selainnya, Thabthabâi justru menekankan keberagaman wujud dalam satu sisi merupakan kesatuan wujud pada sisi lain, penggunaan kata Wahdat atau Wihdat menunjukkan adanya keasdaran bahwa ada wujud yang lebih dari satu yang harus disatukan--hanya saja penyatuan dalam pendirian Mulla Shadra dan Thabthabâi tidak berarti menegasikan selainnya tetapi menyatukan secara eksistensial dalam bentuk tingkatan-gradualitas (tasykiîk). Dalam bahasa yang lebih sederhana Thabthabâi berpendirian bahwa secara Eksistensi Wujud Tuhan dengan Wujud Alam dalam berbagai tingkatannya memiliki tingkat kemurnian yang setara sehingga dapat disatukan dalam konsep Wâjibul al-Wujûd, namun karena dalam realitas terdapat kebertingkatan maka wujud Tuhan menjadi berbeda secara kualitas dengan wujud alam semesta yang menyebabkan wujud selain Tuhan secara niscaya membutuhkan wujud Tuhan.

Mulla Shadra memandang bahwa realitas wujud-wujud bukanlah sebagai objek-objek yang ada dan banyak (al-Maujudât) tetapi merupakan realitas yang tunggal. Adapaun kenakearagaman wujud-wujud yang terlihat seolah banyak sesungguhnya hanya disebakan oleh pembatasan realitas tunggal tersebut oleh esensi-esensi (Mâhiyât). Berbdeda dengan pandangan Ibnu Arabi yang melihat bahwa wujud-wujud yang ada dan beragam merupakan pentazallian atau minfestasi dari Wujud Tuhan lewat nama-nama dan sifat-sifat-Nya. Wujud-wujud itu tidak bersifat murni sebagai wujud tetapi hanya merupakan bayangan yang lebih besifat esensial (Mâhiyat). Dengan kata lain Shadra memandang kehadiran enensi-esensi (Mâhiyât) menjadi penyebab realitas yang tunggal seolah beragam. Sedangkan Ibnu Arabi memandang kehadiran esensi-esensi (Mâhiyât) tersebutlah yang tampak seolah-oleh berwujud namun hakikatnya semu karena hanya ada satu wujud pada eksistensinya. ${ }^{20}$

Ketiga, doktrin ketiga dari Filsafat 'Irfan tersebut adalah konsep ashâlah al-wujûd yang bermakna bahwa wujud adalah ungkapan bagi realitas secara mutlak yang mau tak mau pasti kita akui keberadaannya (al-Wâjib al-Wujuûd) dan Tasykîk al-Wujûd atau fakta dgradasi wujud. ${ }^{21}$ Konsep ini menegaskan kembali bahwa realias wujud bersifat tunggal sehingga keseluruhan konsep lain yang terdapat dalam perbendaharaan bahasa manusia yang dalam istilah para filsuf disebut dengan mâhiyyah

\footnotetext{
${ }^{20}$ Mulyadi Kartanegara, Menyelami Lubuk Tasawuf, (Erlangga, 2006) hal. 36-38.

${ }^{21}$ Thabathabâi, Nihâyat... hal. 14
} 
adalah rekaan atau perspesi manusia (i'tibâriyyah) semata. Dengan kata lain dapat dikatakan bawa semua konsep selain wujud hanyalan batasan konseptual atau ilustrasi dari wujud. ${ }^{22}$

Untuk memudahkan pemahaman atas adanya fakta keberbilangan wujud yang tampak dibalik realitas tunggal maka Filsafat 'Irfan mengedepankan prinsip yang disebut dengan tasykik al-wujûd. Konsep ini menegaskan bahwa batasan-batasan wujud yang muncul disebabkan oleh kehadiran esensi-enesni telah menjadikan wujud mengalami gradasai tingkatan-tingkatan namun tetap dalam suatu realitas yang tunggal. Thabthabâ menyatakana bahwa wujud yang mutlak itu merupakan kenyataan atau realitas yang bertingkat-tingkat. ${ }^{23}$ Untuk menjelaskan konsep ini Shadra maupun Thabthabâi mengambil contoh dari konsep Isyrâq24 --- pencahayaan. Matahari sebagai Wujud Mutlak menempati posisi tertinggi atas tingkatan cahaya, sementara realitas cahaya yang beragam berada dibawahnya dengana tetap tidak ada indikasi bahwa realitas cahaya yang tampak memiliki eksistensi yang berbdeda dari matahari itu sendiri.

Keempat, adapun doktrin keempat dari Filsafat 'Irfan adalah pendirian tentang gerakan yang sustainabilitas pada wujud. Thabthabâi seperti halnya Mulla Shadra berpendirian bahwa wujud sebagai realitas tunggal yang menampung tingkata wujud mestilah mengalami pergerakan. Artinya keseluruhan wujud dalam tingkatannya telah melakukan gerakan evolutif sebagai bagian dari fitrahnya secara eksistensial yang dipopulerkan dengan konsep Al-Harakah al-Zauhâriyyah yang berarti evolusi substansial. Bagi Mulla Shadra gerak tidak hanya terjadi pada empat kategori aksiden: kuantitas, kualitas, posisi dan tempat seperti yang dianut oleh Mazdhab Paripatetik yang mengelaborasi teori Gerak Aristotels. Shadra meyakini bahwa gerak bias terjadi pada susbtansi tanpa sama sekali merubah bentuk. Untuk mendekatkan pemahaman atas

22 Thabathabâi, Nihâyat... hal. 20

23 Thabathabâi, Nihâyat... hal. 24

24 Siukhrawardi menjelaskan bahwa pada hakikatnya cahaya bersifat tunggal sebagai suatu kesatuan namun kemudian ia berbda-beda tingkat dan intensitasnya disebakan adanya bazakh-barzakh yang menyela di antaranya. Karenanya semakin jauh sebuah cahaya dari sumbernya yakni Nûr al-Anwâr, maka semakin reduplah ia karena sebagian intensitas cahaya yang dimilikinya terserap oleh barzakh-barzakh atau esensiesensi yang mengitarinya seperti halnya kaca riben yang tetap dapat menembuskan cahaya yang menyinarinya tetapi sebagai cahaya terserap olehnya hingga tersisa hanya sebagaian yang dapat menembus. Lihat, Muyadi Kartanegara, Integrasi I/mu..... Hal. 3536. 
teori tersebut dapat diluhat misalnya pada gerakan yang dialami oleh kuku. Kuku tangan yang dimiliki sorang bayi yang tampak lembut, kemudian soelah berubah ketika dia dewasa dengan menjadi kasar tanpa terjadi perpindahan dan bahkan perubahan bentuk. Contoh lain yang dapat dilihat pada alam eksternal berupa perubahan benda material dari keadaan yang satu ke keadaan yang lain. Buah apel berubah dari hijau, kemudian kuning, kemudian merah. Ukuran, rasa, berat juga selalu mengalami perubahan. Karena keberadaan aksiden bergantung pada keberadaan substansi.

\section{FILSAFAT KETUHANAN THABTHABÂI}

Pembahasan tentang ketuhanan menjadi salah satu topik penting dalam pemikiran Thabthabâi yang dalam karyanya dimasukkan dalam Bab Mâ Yataâallqu bi al-Wâjib al-Wujûd, dimana melalui pendekatan 'Irfan yang dikembangkannya ia mampu memberikan sejumlah sintesa atas keputusan-keputusan filosofis yang dirumuskan pendahulunya. Sejalan dengan Ibnu Sina, Thabthabâi berpendirian bahwa secara mandiri manusia dapat menemukan keberadaan Tuhan meskipun tidak dibantu oleh wahhyu, sebab kecenderungan untuk menemukan Tuhan telah menjadi fitrah yang diperoleh akan secara hudhûry dan takwiný.

Thabthabâi memandang bahwa pembuktian keberadaan Tuhan atau al-Wâjib al-Wujûd dapat dilakukan melalui metode al-Burhân alLimmi (demonstrasi poter quid) dan al-Burhân al-Inni (demonstrasi quid). Metode al-Burhân al-Limmi (demonstrasi poter quid) adalah metode yang dibangun karena adanaya sebab ('illah) yang mengharuskan adanya akibat (ma'/ûl). Sementara metode yang dimalui dari adanya akibat (ma' 'lûl) menuju adanya keniscayaan adanya sebab ('illah). Lewat metode ini Thabthabâi telah mengeritik sekaligus menguatkan juga metode Causality yang biasanya digunakan para teolog dalam membuktikan keberadaan Tuhan. Lewat metode al-Burhân al-Inni (demonstrasi quid) dapat dilakukan pembuktian maka keberadaan Tuhan yang betolak dari kekhususan wujud dari segi ia maujud, dimana kekhususan maujud ini berlaku sama kemaujudan secara universal. ${ }^{25}$

Mengikuti argumentasi ini, menurut Thabthabâi para Fisikawan (atThabi iyyûn) ${ }^{26}$ memperkenalkan metode lain yang disebut Burhân alHarakah (demonstrasi gerak). Teori ini berangkat dari teori keniscayaan

25 Thabathabâi, Nihâyat... hal. 270-271

${ }^{26}$ Thabathabâi, Nihâyat... hal. 271 
gerakan yang menuntut adanya penggerak. Keberadaan penggerak yang akan berlangsung tanpa ujung mengharuskan adanya pula penggerak yang tidak bergerak yang seterusnya diyakini sebagai penggerak pertama yang tidak bergerak. Penggerak yang tidak bergerak dan tidak tergerakkan tersebut diyakini bebas dari materi dan aksiden-aksiden atau potensi yang kemudian inilah yang diyakini sebagai al-Wâjib al-Wujûd li alZat atau Tuhan. ${ }^{27}$

Teori gerakan ini mesti disudahi dengan meniscayakan adanya penggerak pertama yang tidak bergerak, sebaba jika tidak maka akan terjadi lingkaran pergerakan antara penggerak dengan yang digerakkan. Untuk memudahkan penyelesaian pemutusan siklus penggerak dan yang digerakkan mesti dikedepankan teori keniscayaan suatu zat yang tidak mungkin disifati dengan dua sifat yang saling kontradisksi dalam suatu waktu. Sehingga muncullah dua kategori "penggerak" dan "digerakkan" dimana ketika satu zat disifati sebagai penggerak yaitu al-Wâjib al-Wujûd, maka tidak dibenarkan ia dimasukkan kedalam katergori digerakkan, sebab ia sudah mengambil sifat penggerak. Ketika terhadapnya diarahkan pertanyaan seperti "siapa yang menggerakkan penggerak pertama ?", maka pertanyaan tersebut telah melanggar hukum keniscayaan dimana tidak mungkin dua sifat yang bertentangan "penggerak" dan "digerakkan" dialamatkan secara bersamaan kepada suatu zat.

Metode pembuktian lain dikemukakan para teolong yang mereka sebut dengan (burhân al-hudûts). Mataeri yang ada dalam realitas alam ternyata tidak pernah lepas dari gerak dan diam. Sedangkan setiap sesuatu yang tidak lepas dari gerak dan diam, maka tidak lepas pula dari berobah dan setiap yang tidak lepas dari perobahan berarti tidaklah merupakan sesuatu yang abadi melainkan sesuatu yang baru (al-Huduts). Adapun setiap yang baru pastilah membutuhkan sesuatu yang menjadikannya baru yakni (al-Muhdits) dan tentunya bukan materi atau harus berlawanan sifatnya dari materi dan itulah yang diyakini sebagai alWâjib al-Wujûd Tuhan itu sendiri.

Meskipun Thabthabâi memberikan penghargaan terhadap argument-argumen tersebut di atas, namun baginya ketiga argument tersebut belum dapat memuaskan dahaga inteketual atau nalar akal manusia. Untuk menyahuti hal itu ia menyodorkan metode pembuktian baru yang disebut dengan burhan al-Shiddiqîn bermakna demonstarsiorang-orang yang benar. Metode ini merujuk kepada konsep

${ }^{27}$ Thabathabâi, Nihâyat... hal. 272. 
wâjib al-Wujuûd yang memformulasikan bagaimana keberadaan Tuhan dibuktikan oleh wujud Tuhan itu sendiri tanpa membutuhkan zat atau esensi lain untuk pembuktiannya. ${ }^{28}$

Gagasan inilah yang menurut Thabthabâi disebut gagasan orangorang yang benar, sebab dalam hokum dasar berfikir 'Irfan terdapat kaidah bahwa "Suatu wujud hanya bisa dipahami dipahami oleh wujud di atasnya atau oleh wujud yang setara dengannya. Adapun jika ia dipahami oleh wujud dibawahnya maka pastilah pemahamn tersebut akan mengalami degradasi seperti halnya wujud mengalami degradasi dari wujud di atasnya".

Dengan demikian pembuktian keberadaan Tuhan hanya akan selamat jika dilakukan oleh Tuhan sendiri sebab tidak ada wujud lain di atasnya dan tidak pula ada sekutu atau yang setara dengannya. Karena itu, pembuktian dengan menggunakan wujud yang di bawahnya dapat melahirkan pemahaman yang absurd dan jauh dari hakikatnya. Bagi Thabthabâi yang memiliki konsepsi yang dapat diformulasikan untuk lahirnya teori Wujud Tuhan membuktikan sendiri Wujud-Nya adalah perpaduan pemikiran Abu Ali Sina dan Mulla Shadra dimana keduanya memperkenalkan konsep yang mirip yakni Ibnu Sina menyebutnya hukm ash-Shiddiqîn sementara Mulla Shadra menyebutnya dengan burhân ashShiddiqin. ${ }^{29}$

Dalam mengaktualisasikan teorinya hukm ash-Shiddiqîn, Ibnu sina memunculkan konsep pemilahan wujud yaitu: mumkin, wâjib dan mumtaný. Mumkin sendiri merupakan aksiden yang untuk mewujud ia pasti membutuhkan sebab agar ia menjadi ada teraktus. Kebutuhan terhadap sebab ini akan berlangsung tanpa batas dan itu bertentangan dengan hukum akal, karenanya harus diputus dengan adanya sebab yang tidak tergantung kepada seba lain. Sebab yang tidak tergantung kepada sebab inilah yang disebut dengan al-Wâjib al-Wujûd seterusnya dinamakan Tuhan. ${ }^{30}$

Adapaun Mullah Shadra mengedepankan tiga pemilahan wujud yaitu: ashlât al-Wujûd, wahdat al-Wujûd dan tasykik al-Wujûd. Dari konsepsi ini Mulla Shadra menegaskan bahwa bahwa ashlât al-Wujûd yang bermakna konsepsi tentang wujud sebagai prinsip utama realitas, sehingga kehadirannya tidak mungkin ditolak dan kalua ditolak berarti

\footnotetext{
${ }^{28}$ Thabathabâi, Nihâyat... hal. 170.

${ }^{29}$ Achmad Muchaddam Fahham, Tuhan dalam Filsafat... Hal. 75-76.

${ }^{30}$ Achmad Muchaddam Fahham, Tuhan dalam Filsafat... Hal. 76.
} 
penolakan terhadap realitas. Namun wujud yang menjadi prinsip realitas ini mesti memiliki karakter kemurnian dimana keberadaanya tidak boleh tergantung kepada wujud lain sehingga ia dapat disebut sebagai prinsip segala realitas seterusnya disebut sebagai Tuhan.

Langkah berikutnya, Mulla Shadra mengedepankan bahwa wujud yang menjadi prinsip utama realitas mesti bersifat tunggal, sehingga ketika dihubungkan dengan keberagaman wujud di alam semesta, realitas tunggal tidak berarti terpecah dan kemudian berbilang melainkan tetap tunggal meski terkesan ada keberagaman inilah disebut dengan wahdat al-Wujûd atau wihdat al-Wujûd. Seterusnya untuk menghindari munculnya pemahaman phanteisme disatu sisi dan kerancualn konsep ketunggalan dalam keberagaman, maka Mulla Shadra mengedepankan konsep tasykik al-Wujûd- Dimana kemurnian wujud sebagai realitas mengharuskan ketunggalan pada realitas itu sendiri, seterusnya kesan keberagaman yang tampak merupakan efek dari keberadaan barzakh-barzakh atau aksidenaksiden yang menempati sela-sela wujud sehingga wujud seolah berbatas. Keberadaan aksiden-aksiden tersebut selanjutnya mengharuskan adanya gradasi pada realitas tunggal yang seolah-olah menunjukkan adanya keragaman wujud tetapi sesungguhnya ia tetap tunggal. ${ }^{31}$

Thabthabâi sendiri sangata mengangumi teori ini dan menganggap bahwa jika dibandingkan dengan teori-teori lain yang pernah ada, teori inilah yang paling mampu meyakinkan adanya Tuhan. Meskipun Thabthabâi mengangumi teori ini dan tidak melihat ada kelemahan dalam argumentasinya, tetaoi tetap menyodorkan teori baru dalam upaya pembuktian Tuhan yang disebutnya realisme instingtif dibangun diatas karakteristik fitrah manusia. Teori ini dirumuskan dalam dua premis sebagai berikut: Premis Pertama, secara fitrah dalam dirinya manusa pasti menyadari akan realitas dirinya dan alam di sekitarnya sebagai sesuatu yang nyata bunkan hayal. Meskipun nyata, bukan berarti realitas tersebut tidak dapat berubah dan hancur yang kenyataan itu dapat pula disadari dan disaksikan manusia. Atas kesdaran tersebut manusia dalam fitrahnya akan mengakui kebutuhannya untuk bergantung dan terhubung secara terus menerus dengan wujud yang tetap. Hingga muncul kesdaran bahwa jika hubungan dengan wujud tetap ini terputus maka manusia dan alam semesta akan turut hancur dan lenyap. Wujud yang tetap, tidak berubah dan tempat bergantung inilah yang disebut Tuhan dan wujud mutlak.

${ }^{31}$ Achmad Muchaddam Fahham, Tuhan dalam Filsafat... Hal. 77. 
Premis Kedua, kesadaran akan wujudnya yang nyata serta alama di sekitarnya mendorong manusia untuk mempertanyakan sebab-sebab atas berbagai peristiwa yang dialaminya dan disaksiaknnya pada fenomena di sekitarnya, hingga kemudian ia akan mempertanyakan apakah alam semesta ini bersama seisinya ada dengan sendirinya atau memperoleh wujudnya dari sesuatu yang lain. Hingga kemudian muncul kesdaran dari dalam dirinya yang menyimpulkan bahwa dirinya dan alam semesta tidak mewujud dengan sendirinya, mesti ada satu sandaran yang merupakan sumber wujud, serta sumber kekuasaan dan pengetahuan dialah Tuhan sumber segala maujud dan system eksistensi. ${ }^{32}$

Susunan premis pada realism instingtif ini dibangun diatas konsepsi filsafat yang dipadukan dengan Teologis. Sehingga argument-argumennya lebih sederhana daripada burhân ash-Shiddiqîn. Karenanya Thabthabâi menyebut teori ini sebagai teori pengenalan Tuhan menurut al-Qurân. Hal ini bertolak dari pandangannya bahwa di dalam al-Qurân ditemukan banyak ayat yang menyeru manusia untuk memperhatikan dan menyelidiki alam sekitar untuk menemukan bukti adanya Tuhan. ${ }^{33}$

\section{E. KONSEP ILMU PENGETAHUAN THABTHABÂI}

Sebagai penerus Mulla Shadra, tentu saja pembahasan tentang ilmu memiliki posisi penting dalam Filsafat Thabthabâi meskipun secara spesifik Thabthabâi tidak memiliki karya dalam bidang ini. Jika diamati secara mendalam, akan tampak bahwa konsepsi wujud yang diperkenalkan Mulla Shadra dapat menjadi titik tolak pembaharuan konsepsi ilmu pengetahuan secara menyeluruh, mulai dari ranah ontologi, epistemologi hinnga aksiologinya. Keputusan Shadra tentang adanya wujud sempurna sebagai satu-satunya realitas tunggal (ashlah al-Wujûd menuju wahdat al-Wujûd) dapat menjadi dasar rumusan ontologis dan epistemolgis untuk melahirkan konsep integrasi ilmu pengetahuan (unity of sciences). Mulla Shadra menyatakan bahwa segala wujud yang ada dengan segala bentuk dan karakternya pada hakikatnya adalah satu dan sama, adapun yang membedekan satu dengan lainnya adalah gradasinya (tasykik al-Wujûd) yang disebabkan oleh perbedaan pada esensinya. Oleh karena mereka pada dasarnya satu dan sama, maka wujud apapun yang

\footnotetext{
32 Thabthabâi, Inilah Islam.... Hal. 49.

33 Thabthabâi, Inilah Islam.... Hal. 50-54.
} 
kita ketahui baik berupa realitas spiritual maupun material mempunyai satus ontologis yang sama-sama kuatnya dan sama-sama rillnya. ${ }^{34}$

Para Filsuf Islam berpendirian bahwa ilmu, kesadaran dan ma'rifat, adalah satu dan merupakan bagian dari konsepsi bukti keberadaan diri, yang bebas dari genus logis dan differensia. ${ }^{35}$ Akan tetapi mereka tetap menganggap, bahwa karena ketiga elemen ini juga tetap harus dijelaskan secara filosofis, maka menjadi penting memberikan penjelasan filosofis dan analitis atas ketiga elemen tersebut ketika membahas topik ilmu.

Thabathabâi mendefenisikan ilmu pengetahuan sebagai kehadiran sesuatu yang immaterial di dalam wujud immateri yang lain. Dalam konteks ini Thabathabâi tidak memasukkan sesuatu yang bersifat materi dalam defenisi ilmu hudhuri ini, malah mempertegas bahwa yang diketahui itu harus immateri dan ilmu tidak dapat menyinggung hal-hal yang bersifat materi. ${ }^{36}$

Untuk mempertegas hal tersebut, Thabathabâi, membagi ilmu kepada dua jenis: (1) Ilmu Hushûli (Knowledge by Correspondence) dan (2) Ilmu Hudhûri (Knowledge by Presence). Ilmu Hushûli adalah pengetahuan yang kita peroleh dari objek yang ada diluar diri kita secara objektif. Sebagai contoh pengetahuan kita tentang meja atau tentang sebuah gelas yang ada di atas meja. Dalam konteks ini proses mengetahui adalah interaksi indrawi terhadap objek di luar diri yang kemudian menyebabkan nalar atau pikiran mampu memperoleh sebuah gambaran atau konsepsi (al-Tashawwur).

Sedangkan Ilmu Hudûri adalah kehadiran quiditas yang diketahui (the known) pada yang mengetahui (the knower). Dalam konteks ini setiap sesuatu yang ada di hadapan kita memiliki dua objek: Objek

${ }^{34}$ Mulyadi Kartanegara, Integrasi I/mu...hal. 35.

${ }^{35}$ Bandingkan dengan, Al-Baqillâni yang mendefenisikan ilmu sebagai "Ma 'rifat al-syai ' $i$ 'alâ Mâ Huwa Bihi" yakni pengetahuan tentang sesuatu sebagaimana adanya. Lihat, Franz Rosenthal, Knowledge Triumphant: The Concept of Knowledge in Medieval Islam (Leiden: E.J. Brill, 1970), hal. 53

36 Bandingkan dengan Wan Mohd Wan Daud, yang menyatakan bahwa Ilmu Pengetahuan dalam bahasa Arab digambarkan dengan istilah al-ilm, al-ma'rifah, dan assyu'ur (kesadaran). Namun, dalam pandangan dunia Islam, yang pertamalah yang terpenting, karena ia merupakan salah satu sifat Tuhan adalah al-'Aalim, al-'Aliim dan al'Allam, yang semuanya berarti Maha Mengetahui; tetapi Dia tidak pernah disebut al-'Arif atau as-Sya'ir, (Wan Mohd. Nor Wan Daud, The Concept of Knowledge in Islam and its Implications for Education in developing Country, terj. Munir, Konsep Pengetahuan dalam Islam, Bandung: Pustaka, 1997 M. 65). 
Pertama, berupa Objek Subjektif atau Objek Internal ${ }^{37}$ yang ada atau hadir dalam jiwa atau pikiran kita, dan Objek Kedua, berada diluar jiwa dan pikiran kita. Objek yang ada dalam jiwa kita disebut sebagai "makna", sedangkan yang berada di luar jiwa kita disebut bentuk atau "Sûrah".

Allamah Thabathabai dalam bukunya Bidayat al-Hikmah mengemukakan bahwa manusia memiliki ilmu hushuli, yaitu ilmu tentang perkara-perkara eksternal dengan jalan hadirnya perkara eksternal tersebut melalui esensinya dan bukan melalui eksistensi eksternalnya. ${ }^{38}$ Contohnya: ilmu tentang gunung, maka yang diketahui atau yang hadir adalah gambaran tentang gunung, bukan gunung itu sendiri. Begitu juga dengan mengetahui rumah dan benda-benda yang ada disekitar kita.

Ilmu Hushûli memungkinkan untuk tidak memperoleh kebenaran secara utuh, sebab ia bersumber dari kesimpulan atas upaya subjek untuk merumuskan gambaran dari penghubungan (Correspondence) antara makna dan bentuk. Kalau korespondensi tersebut berkorelasi positif tercapailah kebenaran, tetapi jika melahirkan korelasi negatif akan menjadi salah. Berbeda dengan Ilmu Hudhûri yang dapat secara langsung dapat menangkap makna yang hakiki karena makna tersebut telah hadir dalam jiwa atau subjek. Dengan kata lain Ilmu Hudhûri sebenarnya tidak membahas objek yang ada diluar jiwa karena objek tersebut justru sedang absen sehingga tidak dapat dipahami secara intuitif, melainkan membahas tentang makna yang telah hadir dalam jiwa dan karena kehadirannya dalam jiwa, kita akan dapat memahaminya seperti halnya memahami diri kita sendiri. Pemahaman atau pengetahuan kita terhadap diri kita sendiri bukanlah pengetahuan yang diperoleh melalui representasi (bi alTashawwur) tetapi tetapi diperoleh melalui makan (bilma 'na). ${ }^{39}$

Uraian ini telah mempertegas pendirian Thabthabâi yang mengeluarkan materi dari lingkup ilmu pengetahuan, sebab pengethauan dipahami sebagai bersumber dari Objek Subjektif atau "Makna" yang hadir dalam jiwa subjek yang tentu saja tidak merupakan mater (al-Mâddah). Haidar Bagir menuliskan bahwa penganut Filsafat Hikmah seperti Thabthabâi berpendirian bahwa Ilmu Pengetahuan sebagian bersifat

37 Objek Internal adalah yang hadir di dalam jiwa atau fikiran kita dan identik dengan eksistensi kekuatan persepsi kita. Ini adalah objek subjektif (objek imanen) yang mengonstitusi esensi tindak memersepsi kita yang imanen, yang realitasnya termasuk dalam realitas persepsi kita. Lihat, Mehdi Hairi Yazdi, Epistemologi Iluminasionis dalam Filsafat Islam: Menghadirkan Cahaya Tuhan. Terj. Ahsin Muhammad, (Bandung: Mizan, 2003), Hal. 80-81

${ }^{38}$ Allamah Muhammad Husain Thabthabâi, Bidayat ....... Hal. 139

39 Lihat Mulyadi Kartanegara, Menyelami Lubuk Tasawuf..... Hal.131-133. 
Hushûli, sebagain bersifat Hudhûri dan sebagian lagi merupakan kombinasi keduanya. Ada jenis ilmu yang besifat Hushûly tetapi didahului Hudhûry, sebaliknya ada pula ilmu yang bersifat Hudhûry tetapi didahului Hudhûri, da nada yang murni Hudhûry yang biasanya terkait dengan subjek seperti keadaan-keadaan jiwa. ${ }^{40}$

Thabathabai berpandangan bahwa untuk mencapai pemahaman lewat Ilmu Hushûli perlu dipahami beberapa konsep berpikir sebagai berikut : Pertama, Konsep real atau konsep esensial (konsep mahuwi) bias juga disebut (whatish concept; al-mafahim al-mahuwiyyah) atau konsep primer (first intelligibles; ma'qul awwali) yaitu konsep yang mewujud baik di dalam akal maupun di luar akal, misalnya manusia dan pepohonan. Konsep ini mencakup konsep-konsep universal yang diabstraksikan akal setelah menangkap konsep-konsep partikular. Artinya, akal secara otomatis mengabstraksikan konsep universal esensial dari beberapa pengetahuan particular yang didapatkannya dari indera atau intuisi batin. Contohya : konsep jin, konsep mansia, konsep takut, warna merah dll. Dari satu sisi, konsep esensial merupakan segi kesamaan sekelompok pengetahuan particular, dan dari sisi lain, konsep ini terlepas dan bebas dari ciri-ciri khusus setiap pengetahuan particular tersebut. Karena itu, konsep esensial dapat diterapkan pada individu-individu di alam luaran yang tidak terbatas.

Kedua, Konsep filosofis (philosophical concept; al-mafahim alfalsafiyyah) disebut juga sebagai konsep sekunder (ma'qulat al-tsaniyah al-falsafiyah), yaitu konsep universal yang diperoleh melalui pengamatan akal melalui upaya membandingkan beberapa hal yang dipersepsikan. Contohnya : konsep sebab-akibat yang diperoleh setelah mengamati relasi dari dua hal. Konsep ini mampu menjelaskan hubungan-hubungan di antara entitas-entitas luaran dan ciri-ciri khas eksistensialnya, tetapi sebenarnya ia tidak memiliki eksistensi di luar tetapi hanya ada di dalam mental unsich. Sehingga konsep-konsep filsafat merupakan kualitas atau atribut untuk realitas-realitas objektif.

Ketiga, Konsep pemahaman logis dan saintis : Yaitu hasil figurative suatu persepsi yang meminjam konsep real untuk kemudian dimanifestasikan dalam kehidupan manusia. Konsep yang dicapai dan digunakan demi kepentingan sains serta untuk tujuan kehidupan manusia lainnya. Tidak memiliki terma logis sehingga tidak bisa dijelaskan dengan bukti demonstrative (burhan). Berbeda dengan konsep esensial, konsep ini

\footnotetext{
${ }^{40}$ Haidar Bagir, Buku Saku Tasawuf, (Bandung: Mizan, 2005), Hal. 2005-206.
} 
tidak memiliki wujud eksternal yang sama. Pandangan yang merujuk pada konsep-konsep ini tidak dapat dinilai benar atau salah, penilaian tentangnya dilakukan melalui persetujuan atau penolakan terhadap tujuan-tujuan konsep tersebut. ${ }^{41}$

\section{F. KESIMPULAN}

Thabthabâi adalah Filsuf dan Ulama besar yang memiliki jasa yang amat penting dalam melanjutkan tradisi Filsafat di Teheran dan Qom. Pemikirannya tentang Wujud, Ketuhanan dan Ilmu seolah menghidupakan kembali Filsuf Besar Mulla Shadra, karena Thabthabâi bukan saja menguasai secara baik Filsafat Shadra, tetapi lebih jauh dapat menghidupkan Filsafat Shadra untuk menyahuti berbagai problem pemikiran Filsafat di era modern.

Menarik diperhatikan, bahwa meskipun secara keseluruhan Filsafat Thathabâi merupakan lanjutan dari Mullas Shadra, tetapi tetap terlihat bahwa Thabthabâi memiliki kekhasan pemikiran yang menjadikan Filsafat Shadra tampak lebih hidup ditangan Thabthabâi, bahkan dalam hal ketuhanan justeru penambahan metode Realisme Instingtif yang digagas Thabthabâi telah menyempurnakan sekaligus menyederhanakan pemikiran Shadra. Filsafat Thabthabâi selain lahir dari kematangan intelektual juga didasarkan pada kematangan spiritual, maka aliran Filsafat ini lebih dikenal dengan sebutan "Hikmah atau 'Irfân" daripada Filsafat. Hikmah (Bidâyat al-Hikmah-Nihâyat al-Hikmah) atau 'Irfân memiliki kekhasan dengan mengintegrasikan capaian akal mustafad (meminjam istilah alFarabi) dengan pemberian "rahim atau luthf" dari Tuhan yang memungkinkan seorang Filsuf dapat terakses dengan Universal Idea "alLauh al-Mahfûzh" sehingga capaian-capaiannya bukan sekadar berderajat spekulatif tetapi lebih bersifat intuitif atau 'irfâny atau disebut juga hudhûry.

${ }^{41}$ Allamah Muhammad Husain Thabathabâi, Nihayat ...., Hal. 243-259. 


\section{DAFTAR BACAAN:}

Ahsan, Abdul Shakoor. "Renaissance in Iran: General" dalam MM. Sharief, (ed) A History of Muslim Philoshophy, Vol II (Pakistan: Royal Book Company, 1983).

Babich, Babette. E. (ed). Hermeneutic Philosophy of Science, Van Gogh's Eyes, and God: Essays in Honor of Patrick A. Heelan, S.J. (Kluwer Academic Publisher 2002).

Bagir, Haidar. Buku Saku Tasawuf, (Bandung: Mizan, 2005).

Fahham, Achmad Muchaddam. Tuhan dalam Filsafat Allamah Thabthaba 'i: Relevansi Pandangan Moral dengan Eksistensi Tuhan dalam Pandangan Realisme Instingtif, (Yogyakarta: Rausyanfikri Institute, 2012).

Kartanegara, Mulyadi. Integrasi IImu: Sebuah Rekonstruksi Holistik, (Arasy Mizan, 2005).

Kartanegara, Mulyadi. Menyelami Lubuk Tasawuf, (Erlangga, 2006).

Mavani, Hamid. Religious Authority and Political Thought in Twelver Shi'ism: From Ali to Post Khomeini, (New York: Roudledge, 2013).

Moris, Zailan. Intellectual Intuition and Reason in the Philosophy of Mulla Shadra: An Analysis of The al-Hikmah al-Arshiyyah, (London \& New York: Roudledge 2003).

Nasr, Seyyed Hossein Nasr. Preface to the Book of Shiite in Islam by Allameh Tabatabaei, (Qum Iran, 2006).

Nasr, Seyyed Hossein. "Muhammad Husain Thabthaba $i "$ (1903-1981) dalam Jhon L. Esposito (ed), Oxford Encyclopedia of Modern Islam World, (New York: Oxford University Press, 1995, Vol 4).

Nor Wan Daud, Wan Mohd. The Concept of Knowledge in Islam and its Implications for Education in developing Country, terj. Munir, Konsep Pengetahuan dalam Islam, Bandung: Pustaka, 1997 M).

Rahman, Fazlu. The Philosophy of Mulla Sadra Shirazi, (Albany: State University of New York Press, 1975).

Reynold, Jack. Understanding Existentialism, (London \&Newyor: Roudlege, 2006).

Rosenthal, Franz. Knowledge Triumphant: The Concept of Knowledge in Medieval Islam (Leiden: E.J. Brill, 1970).

Thabathabâi, Allamah Muhammad Husain. Nihâyat Al-Hikmah, (Qum: Muassasah An-Nasyr Al-Islami, 1422 H). 
Thabthabâi, Allamah Muhammad Husain. "Hidupku" dalam, Inilah Islam: Upaya Mehamai seluruh Konsep Islam secara Mudah, (Bandung: Pustaka Hidayah, 1996).

Thabthabâi, Allamah Muhammad Husain. Bidâyat Al-Hikmah, (Qum: Muassasah An-Nasyr Al-Islami, $1422 \mathrm{H}$ ).

UNESCO: Arab Muslim Civilization in the Mirror of the Universal: Philosophical Perspectives, (UNESCO:2010).

Yazdi, Mahdī Hā'irī. The Principles of Epistemology in Islamic Philosophy: Knowledge by Presence, (New York: State University of New York Press, 1992).

Yazdi, Mehdî Hairi. Epistemologi Iluminasionis dalam Filsafat Islam: Menghadirkan Cahaya Tuhan. Terj. Ahsin Muhammad, (Bandung: Mizan, 2003). 